\title{
KULT SVETOG NIKOLE - MIJENE KROZ POVIJEST I ULOGA U IZGRADNJI SUVREMENOG IDENTITETA DUBROVNIKA
}

\author{
Vinicije B. Lupis - Nikolina Hazdovac Bajić
}

Institut društvenih znanosti Ivo Pilar

Područni centar Dubrovnik vinicije.lupis@pilar.hr nikolina.hazdovac@pilar.hr
UDK: 801.661:27-36Sv. Nikola]94(497.584Dubrovnik) (2-523.6+27-523.42):26-36Sv. Nikola(497.584) 355.469.2(497.584Dubrovnik)“1991.12.6“

https://doi.org/10.34075/cs.56.4.7 Izvorni znanstveni rad Rad zaprimljen 6/2021

\section{Sažetak}

Dubrovnik je važan kulturni i vjerski topos na nacionalnom ozemlju, grad na svojevrsnom raskršću uljudbenih sustava, koji je, uz vjerski $i$ državni kult sv. Vlaha, prepoznat $i$ kao najjužniji grad s urbanim sujetovnim kultom viteza Orlanda. Ovim gradskim vjerskim $i$ sujetovnim kultovima $u$ Domovinskom se ratu pridružio i treći - kult sv. Nikole. Na dan sv. Nikole 6. siječnja 1991. godine zbio se najteži napad srpsko-crnogorskih agresora na grad, pa je stoga taj dan proglašen i Danom branitelja Dubrovnika. Vjerski kult sv. Nikole od 1991. godine dobiva tako posve novu dimenziju i priključuje se drugim urbanim simbolima Grada. Sv. Nikola postaje u suvremenoj memoriji Grada kult sveca zaštitnika branitelja Domovinskog rata. Ovdje se radi o posve jedinstvenom fenomenu u razvoju kulta $s v$. Nikole $u$ sujetskim razmjerima, koji postaje antiratni svetac i svetac obranitelj. Cilj je ovoga rada, na interdisciplinaran način, kombinirajući povijesnu i sociološku perspektivu, steći prvi znanstveni uvid u međusobni odnos koncepata religijskog simbola, identiteta i zajednice na primjeru razvoja, promjene i značenja kulta sv. Nikole u Dubrovniku kroz povijesni kontinuitet do suvremenih zbivanja.

Ključne riječi: sv. Nikola, Dubrounik, simbol, identitet, transformacija kulta

\section{UvOD}

Pitanje identiteta jedno je od ključnih pitanja suvremenog svijeta. Suvremene znanosti odmiču se od modernističkog shvaćanja pojma identiteta koje je taj pojam esencijaliziralo kao singularnu, izvornu i prirodnu kategoriju te se primiču postmodernističkom i poststrukturalističkom shvaćanju identiteta kao fluidnog, nestabil- 
nog i višestrukog (pri čemu može označavati osobni ili grupni identitet, ali i nacionalni, jezični, kulturni, religijski, etnički itd.). Pojam identiteta tako je u posljednjih nekoliko desetljeća teorijski redefiniran u okviru različitih društvenih i humanističkih znanosti, te konceptualno razrađen $\mathrm{u}$ okviru različitih teorijskih pristupa. I u hrvatskom kontekstu, osobito od osamostaljenja i stvaranja suverene države, pitanje identiteta izaziva veliku pažnju, ${ }^{1}$ pri čemu se brojni znanstveni radovi dotiču uloge religije i religijskih simbola $u$ izgradnji identiteta na individualnoj, grupnoj i nacionalnoj razini. ${ }^{2}$ Unatoč rastućem zanimanju za ovo područje, primjetan je nedostatak empirijski utemeljenih interdisciplinarnih istraživanja.

Posebnost hrvatskog nacionalnog identiteta sagledanog kroz baštinsko i vjersko naslijeđe jest u njegovoj raznolikosti, kroz koju se zrcali hrvatska stoljetna zbilja i razni kulturni, kao i politički utje-

1 Stjepan Baloban (ur.), Hrvatski identitet u Europskoj uniji, Centar za promicanje socijalnog nauka Crkve, Zagreb, 2003.; Miljenko Brekalo, Angelina Banović Markovska, Mate Buntić, Snježana Čolić, Maja Jakimovska Tošić, Zlatko Kramarić, Ivica Musić, Krystyna Pieniążek Marković, Sanja Špoljar Vržina, Ivana Žužul (ur.), Kultura, identitet, društvo, Zbornik radova 1. međunarodnog interdisciplinarnog znanstvenog skupa, Sveučilište Josipa Jurja Strossmayera, Institut društvenih znanosti Ivo Pilar, Osijek - Zagreb, 2014.; Ivan Cifrić (ur.), Relacijski identiteti. Prilozi istraživanju identiteta hrvatskog društva, Biblioteka Razvoj i okoliš, Zagreb, 2008.;

Ivan Cifrić, Tijana Trako Poljak, Ksenija Klasnić, Hrvatski identitet $u$ promjeni? Relacijski identiteti 2, Hrvatsko sociološko društvo, Institut za društvena istraživanja, Zavod za sociologiju Odsjeka za sociologiju Filozofskog fakulteta, Zagreb, 2013.; Rade Kalanj, Zov identiteta kao prijeporno znanstveno pitanje, Socijalna ekologija 12 (2003.) 1-2, 47-68.; Željko Heimer, Marin Sabolović (ur.), Simbol, identitet i Domovinski rat, Zbornik radova znanstveno-stručnog skupa, Hrvatsko grboslovno i zastavoslovno društvo, Zagreb, 2016.; Tijana Trako Poljak, Hrvatski simbolički identitet: značenje nacionalnih simbola iz perspektive hrvatskih građana, TIM press, Zagreb, 2016.

2 Ivan Cifrić, Percepcija nekih odnosa crkve i države i uloga crkve i religije u društvu, Sociologija sela, 38 (2000.) 1-2, 227-254.; Franjo Emanuel Hoško, Utjecaj crkvenih elita na nacionalni identitet, Hrvatski identitet $u$ Europskoj uniji, Centar za promicanje socijalnog nauka Crkve, Zagreb, 2003., 51-87; Vinicije B. Lupis, Kult svetoga Vlaha i identitet Dubrovnika u europskom i svjetskom kontekstu, Kultura identitet društvo, Zbornik radova 1. međunarodnog interdisciplinarnog znanstvenog skupa, Sveučilište Josipa Jurja Strossmayera, Institut društvenih znanosti Ivo Pilar, Osijek-Zagreb, 2014., 529-548; Dinka Marinović Jerolimov, Religijske promjene u tranzicijskim uvjetima u Hrvatskoj: promjene u dimenzijama religijske identifikacije i prakse, Sociologija sela 38 (2000.) 1-2, 43-80; Krunoslav Nikodem, Religijski identitet u Hrvatskoj, Socijalna ekologija 13 (2005.), 2-4, 257-285; Andreja Sršen, Katolička Crkva u Hrvatskoj na razmeđu tradicionalnosti i modernosti: Novi prijepori europske stvarnosti, Croatica Christiana periodica, 38 (2014.) 74, 209-223; Tijana Trako Poljak, Percepcija religijskih simbola u hrvatskom društvu: križ, polumjesec i Davidova zvijezda, Socijalna ekologija 20 (2011.) 2, 147-175. 
caji. Položaj na razmeđu civilizacija i utjecaja umnogome je uvjetovao položaj hrvatske nacionalne i vjerske baštine, koja je integralni dio zapadnoeuropskoga kulturnog kruga, a ne tek njezin rubni dio, koji ionako u suvremenim europskim integrativnim procesima biva manje vrednovan usprkos činjenici da održava civilizacijsku sliku hrvatskih prostora. Dubrovnik je važan kulturni i vjerski topos na nacionalnom ozemlju, grad na svojevrsnom raskršću uljudbenih sustava, koji je prepoznatljiv po svojem simbolu - armenskom svecu sv. Vlahu. Tijekom stoljeća od prvotnih svetaca zaštitnika grada Dubrovnika, sv. Srđa i Bakha, preko emancipacije lokalnog kulta svetih Petilovrijenaca, postaje prepoznatljiv po državnom kultu sv. Vlaha, koji je utkan u sve njegove pore. Isto tako grad Dubrovnik je uz vjerski i državni kult sv. Vlaha prepoznat i kao najjužniji grad s urbanim svjetovnim kultom viteza Orlanda. Orlando i sv. Vlaho dva su simbola grada Dubrovnika, neraskidivo vezana svojim simboličnim i duhovnim značajem uz spomen njegova imena, poput sinonima civilizacijskoga i kulturnog dosega ovog dijela Europe. Orlando tijekom 19. stoljeća uz kult sv. Vlaha dobiva i novu političku dimenziju otpora austrougarskoj vlasti. Najvažnija Orlandova uloga je upravo u reinterpretiranom ritualu Feste sv. Vlaha, gdje postaje važnim čimbenikom u samom činu podizanja svečeve zastave na jarbol njegova stupa. Orlandov stup bilježio je najdramatičnije trenutke obrane Dubrovnika u Domovinskom ratu, te tako i sv. Vlaho i vitez Orlando dobivaju posebnu novu simboličku dimenziju hrvatskog otpora srpsko-crnogorskom agresoru, odnosno pripadanja zapadnoeuropskom kulturnom krugu i otpor stranim političkim presizanjima. $^{3}$

Ovim gradskim vjerskim i svjetovnim kultovima u Domovinskom ratu pridružio se i treći - kult sv. Nikole. Grad Dubrovnik u suvremenoj je povijesti iz razdoblja Domovinskog rata posebno vezan uz obilježavanje dana sv. Nikole, jer se na taj dan, 6. siječnja 1991. zbio najteži napad na grad Dubrovnik srpsko-crnogorskih agresora, u kojem su stradali mnogi građani Dubrovnika, kao i kulturni spomenici. U razdoblju srpske i crnogorske okupacije koja je trajala 392 dana, okupator je spalio 60 \% šuma, onesposobio je 65 \% pošta, uništio zračnu luku, radijske i televizijske odašiljače. Veći dio bivše Općine Dubrovnik bio je okupiran, a potpuno su uništene i spaljene 2253 kuće, dok ih je 7745 oštećeno. Od svih sakralnih objekata koliko ih ima na području Dubrovačke biskupije uništeno je ili ošte-

3 Vinicije B. Lupis, Orlandov stup u likovnoj umjetnosti, Katalog izložbe Orlando simbol slobode, Dubrovnik, 2019., 50-194; Maja Nodari, Gradsko štovanje Sveca zaštitnika, Katalog izložbe Sv. Vlaho u povijesti i sadašnjosti, Dubrovnik, 2014., 100-151. 
ćeno njih 31,6 \%. Ako se zbroji 60 uzbuna (općih i zračnih), koliko ih je bilo $u$ tom razdoblju okupacije, onda se dolazi do podatka kako je srpska i crnogorska okupatorska vojska tijekom punih 50 dana sustavno razarala grad i okolicu s kopna, mora i iz zraka. Prilikom bombardiranja nastradalo je više od 200 ljudi. Ranjeno je 267 civila, a više od 300 ih je mučeno u srpskim i crnogorskim koncentracijskim logorima u Morinju i Bileći. ${ }^{4}$ Zbog velikog stradanja civila i grada dan sv. Nikole odabran je za Dan branitelja Dubrovnika. $\mathrm{Na}$ taj dan pijeteta gradske vlasti komemoriraju žrtve Domovinskog rata, a na spomen poginulim braniteljima sagrađena je 2002. godine zavjetna crkva sv. Nikola na groblju u Sustjepanu. ${ }^{5}$

\section{Sv. Nikola Biskup i nJegovo ŠtovanJe u Dubrovniku}

Sv. Nikola, biskup iz maloazijske Mire, pripada onim svecima kršćanske ekumene uz koje je vezano više legenda. Umro je 6. prosinca 327. Pokopan je u Miri. Tijekom seldžučke invazije njegovo su tijelo 9. svibnja 1087. godine 62 vojnika iz Barija prenijela u Bari, kako se ne bi zbila profanacija relikvija. Blagdan 9. svibnja obilježava prijenos moći sv. Nikole u Bari, a sam svetac se štuje kao zaštitnik djece, pomoraca, djevojaka, siromaha, studenata, ljekarnika, pekara, ribara, zatvorenika, trgovaca, putnika, bolesnika, umirućih. ${ }^{6}$ U Dubrovniku je po svemu sudeći došlo i do kontaminacije

4 Ivo Grbić, Srpsko-crnogorska agresija na Dubrovnik 6. XII. 1991., Vlastita naklada, Dubrovnik, 2016., 1-216; Želimir Puljić, Ranjena Crkva u Hrvatskoj, uništavanje sakralnih objekata u Hrvatskoj (1991. - 1995.), Dubrovačka biskupija, Zagreb, 1996, 91-129; Željko Seretinek, Razbijanje pomorske blokade Jadrana 14. - 16. 11. 1991. godine (I. dio), Godišnjak grada Korčule, 4 (1999.), 265-296; isti, Razbijanje pomorske blokade Jadrana 14. - 16. 11. 1991. godine (II. dio), Godišnjak grada Korčule 5 (2000.), 291-334; Janko Bobetko, Sve moje bitke, Vlastita naklada, Zagreb, 1996; Nikola Dobroslavić, Okupacija i oslobađanje područja dubrovačkog primorja 1991. - 1992., Zbornik Dubrovačkog primorja i otoka, 8 (2001.), 235-245.

5 Dostupno na https://www.dubrovnik.hr/vijesti/program-za-dan-dubrovackihbranitelja-6-prosinca-2019-13424 (preuzeto: 29. 6. 2021.).

6 Maria Stella Calò Mariani, I Santi venuti dal mare Atti del V Convegno Internazionale di Studio (Bari - Brindisi, 14 - 18 dicembre 2005), Adda, Bari, 2009., 291-324; Rosa Giorgi, Santi giorno per giorno tra arte e fede, Mondadori Electa, Milano, 2005., 716; Michalee Bacci, San Nicola Splendore d'arte d'Oriente e d'Occidente, Skira, Milano, 2006., 15-30; Marijan Grgić, Nikola, u: Leksikon ikonografije, liturgike i simbolike zapadnog kršćanstva, (ur.) Anđelko Badurina, Kršćanska sadašnjost, Zagreb, 1985., 426-427; Mario Sgarbassa i Luigi Giovannini, Il santo del giorno, San Paolo Edizioni, Milano, 1997., 577-578; Marko Dragić, Sveti Nikola biskup u hagiografskoj baštini Hrvata, Ethnologica Dalmatica, 22 (2014.), 5-42; isti, Sveti Nikola u katoličkoj tradicijskoj kulturnoj i filološkoj baštini, HUM časopis Filozofskog fakulteta Sveučilišta u Mostaru, 5 (2009.), 35-58. 
kulta sv. Nikole, biskupa iz maloazijske Mire (koji postaje sv. Nikola iz Barija ili Biskup) sa sv. Nikolom Putnikom. Sveti Nikola Putnik zaštitnik je grada Tranija, umire 1094. u tom gradu na glasu svetosti, a samo nekoliko godina poslije smrti papa Urban II. ga kanonizira. Blagdan ovoga mladog grčkog hodočasnika rođenog 1075. u Stiru u pokrajini Fokidi obilježava se 2. lipnja. Sv. Nikola Putnik zaštitnik je mladih i hodočasnika. ${ }^{7} \mathrm{U}$ starom Dubrovniku častio se i sv. Nikola Tolentinski, na 10. rujna, čija je crkva u današnjoj Androvićevoj ulici bila sagrađena 1467. godine. ${ }^{8}$

\section{Cilu I Metode}

Ovaj rad nastoji na inovativan način povezati prvi cjeloviti povijesni prikaz kulta sv. Nikole u Dubrovniku te ga obogatiti sociološkom analizom njegove promjene i razvoja iz tradicionalno-religioznog u suvremeno-nacionalni simbola Grada. Na taj način nastoji pridonijeti razumijevanju lokalne zajednice kao fenomena proizašlog iz osjećaja pripadnosti zajedničkom identitetu utemeljenom na zajedničkim simbolima, vrijednostima, normama i moralnom kodeksu. ${ }^{9}$ Drugim riječima rad na konkretnom primjeru nastoji analizirati međusobni odnos teorijskih koncepata (religijskog) simbola, identiteta i zajednice. U tom je smislu fokus rada ujedno analitički i deskriptivan, te usmjeren na povijesnu i sociološku analizu konkretnog simbola kao bitnog za razumijevanje formiranja identiteta članova zajednice $u$ povijesnom kontinuitetu do danas.

Cilj ovog rada je stoga steći prvi interdisciplinarni znanstveni uvid u međusoban odnos koncepata religijskog simbola, identiteta i zajednice na primjeru razvoja, promjene i značaja kulta sv. Nikole u Dubrovniku u povijesnom kontinuitetu do suvremenih zbivanja.

Osnovna istraživačka pitanja koja su usmjerila istraživanje glase: 1. Kakva je simbolička uloga kulta sv. Nikole u Dubrovniku tijekom povijesti i očuvanja dubrovačke dijaspore na Kosovu u Janjevu? 2. Koji su materijalni i nematerijalni pokazatelji značenja kulta sv.

7 Mons. Sabino Amedeo Lattanzio (ur.) I nostri santi patroni, Editrice Rotas, Barletta, 2009., 18-25; Corrado Tridente, Un santo pellegrino in Puglia: San Nicola di Trani, Rotte mediterranee della cultura. u: Il cammino di Gerusalemme, Atti del II Covegno Internazionale di Studio (Bari-Brindisi-Trani, 18-22 maggio 1999), Adda, Bari, 2002., 363-372. Zanimljiva je činjenica kako se u knjizi Leksikon ikonografije, liturgike i simbolike zapadnog kršćanstva uopće ne navodi sv. Nikola Putnik, te je posve nepoznat u hrvatskoj znanstvenoj literaturi.

8 Lukša Beritić, Ubikacija nestalih gradjevinskih spomenika u Dubrovniku, u: Prilozi povijesti umjetnosti u Dalmaciji, 10 (1956.), 56-57.

9 Anthony P. Cohen, The Symbolic Construction of Community, Routledge, London, 2000. 
Nikole u Dubrovniku tijekom povijesti? 3. Koji su članovi zajednice nositelji kulta sv. Nikole u Dubrovniku tijekom povijesti? 4. Na koji način se kult sv. Nikole doživljava danas među dubrovačkim braniteljima? 5. Na koji način se kult sv. Nikole doživljava danas među dubrovačkim pomorcima? 6. Koji su rituali povezani s kultom sv. Nikole tijekom povijest i danas?

Povijesni dio rada temelji se na prikupljanju i analizi povijesne i arhivističke građe, dostupnih povijesnih izvora i materijalne baštine. Hagiografsko-povijesno istraživanje vodit će brigu o univerzalnosti ovog kulta u kršćanskim denominacijama Istoka i Zapada, te uklopljenosti Dubrovnika u sredozemni kulturni krug, kao dio općega kršćanskog identiteta, cilja hodočašća i pomorstva kao baze na kojoj je izrastao Dubrovnik. Sociološki dio rada s ciljem analize specifičnosti odabranog simbola u dubrovačkom kontekstu temelji se na kvalitativnoj metodologiji, odnosno provedbi niza polustrukturiranih intervjua s dvije skupine građana s posebnim odnosom prema kultu sv. Nikole: pomorcima i braniteljima Dubrovnika. Planirani broj intervjua je 10-15 za svaku skupinu ispitanika, budući da oko tog broja provedenih intervjua dolazi do saturacije ili zasićenja, odnosno sljedeći intervjui ne donose nove podatke značajne za temu istraživanja. ${ }^{10}$ Protokol za intervju sadržao je 8 pitanja usmjerenih na značenje koje je sv. Nikola imao za sugovornike prije Domovinskog rata, koje ima danas (na emotivnoj i vrijednosnoj razini), specifičnosti vezane uz rituale oko blagdana sv. Nikole (u prošlosti i danas, te njihove razlike i preklapanja). Prije provedbe intervjua sugovornici su dali informirani usmeni pristanak istraživačima, kao i pristanak na audio snimanje sadržaja intervjua. Sugovornici su informirani o svrsi i ciljevima istraživanja, o dobrovoljnoj prirodi istraživanja, o mogućnostima za upoznavanje s rezultatima i o načinu korištenja i čuvanja prikupljenih podataka. Sadržaj svakog intervjua anonimiziran je tako da su sugovornicima promijenjena imena i ostali podaci koji bi mogli upućivati na njihov identitet. Intervjui su održavani prema unaprijed dogovorenom vremenu i mjestu, uglavnom putem posrednih video kanala, budući da su se odvijali za vrijeme pandemije virusa COVID-19. Prosječno trajanje intervjua iznosilo je 15 minuta. Uz pomorce i branitelje dodatno je obavljeno i pet intervjua s pripadnicima manjine $\mathrm{s}$ Janjeva $^{11}$ (uz isti protokol). Ovim se nastojalo samo indikativno naznačiti postojanje dodatnog sloja

10 Mark Mason, Sample Size and Saturation in PhD Studies Using Qualitative Interviews, Forum: Qualitative Social Research, 11 (2010.) 3, 1-19.

11 Premda je broj intervjua održanih s pripadnicima janjevske manjine manji od predviđenog (10-15), ipak je i na ovom broju intervjua došlo do saturacije nalaza 
značenja, vrijednosti i emocija vezanog uz simbol sv. Nikole za ovu manjinsku zajednicu.

Sugovornici za intervjue odabrani su snowball metodom. Po završetku istraživanja raspolagali smo s 29 intervjua (12 s pomorcima, $12 \mathrm{~s}$ braniteljima, $5 \mathrm{~s}$ pripadnicima janjevske manjine). Svi su intervjui transkribirani verbatim odmah po završetku ili u što kraćem vremenu po završetku. Obrada materijala prikupljenih intervjuima vršila se programskim paketom NVivo, na način da su najprije određene glavne teme: značenje sv. Nikole u prošlosti, značenje sv. Nikole danas, rituali (u prošlosti i danas), razlike i sličnosti između odnosa prema simbolu sv. Nikole u prošlosti i danas (u emotivnom i vrijednosnom smislu), a potom kodovi unutar glavnih tema.

\subsection{Povijesni pregled razvoja kulta sv. Nikole u Dubrovniku - Moćnici sv. Nikole}

U Moćniku Gospe Velike u Dubrovniku čuva se više moćnika oba sv. Nikole. Radi se o tri moćnika: moćnik ruke sv. Nikole Biskupa i sv. Barbare (XXI) iz druge polovice 14. stoljeća, moćnik noge sv. Nikole Putnika (XXVI) iz sredine 14. stoljeća te moćnik noge sv. Nikole Putnika (CXVI) iz sredine 14. stoljeća. ${ }^{12}$ Zanimljivo je da su svi moćnici nastali u 14. stoljeću, a u drugim dubrovačkim crkvenim riznicama ne nalazimo moćnike sv. Nikole. Važno je spomenuti kako su Dubrovčani godine 1203. sklopili ugovor s gradom Termolijem, koji je pod zaštitom sv. Nikole Putnika. Godine 1201. sklopili su i ugovor s gradom Barijem, koji je nakon translacije relikvija sv. Nikole iz Mire (Biskupa) 1087. godine pod njegovom zaštitom. ${ }^{13} \mathrm{U}$ Zadru se tako čuva gotički relikvijar glave sv. Nikole iz 14. st. stoljeća koji je izvorno pripadao samostanu klarisa sv. Nikole u Zadru. ${ }^{14}$ Šrenje relikvija i kulta sv. Nikole u 14. stoljeću zasigurno trebamo tražiti u činjenici kako je to povijesno razdoblje kada su na hrvatskougarskom prijestolju bili Anžuvinci, gospodari talijanskog juga.

budući da se radi o relativno maloj zajednici koja ima zajedničke običaje, vrijednosti i njeguje kult sv. Nikole na specifičan način.

12 Vinicije B. Lupis, Moćnik dubrovačke prvostolnice, Neobjavljena doktorska disertacija, Filozofski fakultet Zadar, 2003., 182-183, 186, 235; isti, Moćnik katedrale, u: Katedrala Gospe Velike u Dubrovniku, (ur.) Katarina Horvat-Levaj, Artresor, Dubrovnik - Zagreb, 2014., 416, 419, 420; isti, Dubrovačke srednjovjekovne zlatarske teme, Institut društvenih znanosti Ivo Pilar, Zagreb - Dubrovnik, 2015., $110,111,119$.

13 Josip Lučić, Dubrovačke teme, Nakladni zavod Matice hrvatske, Zagreb, 1991., 59.

14 Nikola Jakšić, Kataloška jedinica 27, u: Umjetnička baština Zadarske nadbiskupije, zlatarstvo, Zadar, 2004., 80-82. 


\subsection{Kult sv. Nikole u Dubrovniku}

U samome je Dubrovniku sv. Nikola bio zaštitnik Bratovštine mesara na Prijekome i brodograditelja tijekom 16. stoljeća. Kult sv. Nikole na području Dubrovačke Republike iznimno jača, prateći konjunkturu pomorstva tijekom 15./16. stoljeća, te u 18. stoljeću, što se može zorno pratiti uz gradnju crkava, kapela, samostana, oltara i imenovanja jedrenjaka. ${ }^{15} \mathrm{~Sv}$. Nikola nije nikada bio važan kult u Dubrovačkoj Republici i nije ulazio u važnije blagdane na državnoj listi blagdana, već je ostajao u domeni strukovnog i obiteljskog sveca. ${ }^{16}$ U crkvi sv. Nikole na Škaru u Gružu 1594. godine spominje se Bratovština sv. Nikole, a gruški župnik dum Mato Vodopić je 1867. izradio pravilnik za bratstvo koje nosi naslov „Osnova pravila Bratstva Svetoga Nikole od Škara u Gruži“. Pravilnik je sastavljen sa svrhom brige i zaštite interesa svih članova Bratstva (meštara, kalafata, pomoraca). Bratstvo je bilo vid sindikalne organizacije svoga vremena. ${ }^{17}$ U gradovima Splitu i Kotoru sv. Nikola je bio zaštitnik pomoraca i njihovih bratovština, a sijelo glasovite Bratovštine pomoraca $u$ Kotoru upravo je bilo u crkvi sv. Nikole mornarâ. Tu je crkvu u prvoj polovini XIV. stoljeća sagradio kotorski vlastelin Tripo Buća, a njezinu gradnju darovala je njegova žena Belka, oporukom iz 1353. godine. ${ }^{18}$ Druga već spomenuta poznata bratovština bila je Bratovština splitskih pomoraca - La mariegola de l scuola di marineri de San Nicola di Sdoria s kraja 14. stoljeća. ${ }^{19}$ Na Prijekome u Dubrovniku predromanička crkva sv. Nikole bila je središnje okupljalište vjernika na svečev blagdan, uz pučki običaj dijeljenja jabuka neoženjenim pripadnicima zajednice. Sv. Nikola u Dubrovniku imao je obiteljsku dimenziju darivanja djece te zazivanja blagoslova na pomorce dubrovačkoga kraja. Kult sv. Nikole nesumnjivo se iz bizantskog Barija proširio u Ragusium, tada dio bizantske teme Gornje Dalmacije tijekom 11. i 12. stoljeća,

15 Kao ilustrativni primjer treba navesti podatak oko 40 peljeških jedrenjaka pod imenom sv. Nikole Biskupa i sv. Nikole Tolentina (vidi: Stjepan i Nenad Vekarić, Tri stoljeća pelješkog brodarstva, Društvo Pelješčana, Zagreb, 1987, 365-366.

16 Nella Lonza, Kazalište vlasti, ceremonijal i državni blagdani Dubrovačke Republike u 17. i 18. stoljeću, Hrvatska akademija znanosti i umjetnosti - Zavod za povijesne znanosti HAZU u Dubrovniku, Zagreb/Dubrovnik, 2009., 232.

17 Ante Dračevac, Odnos među Bratovštinama stare Gruške parokije, Croatica Christiana periodica, 27 (1991.), 97-106; Luko Bradarić, Zapisi iz lapadske prošlosti, Matica hrvatska Dubrovnik, Dubrovnik, 2001., 41.

18 Slavko Mijušković, Bokeljska mornarica, 12 vjekova bokeljske mornarice, Monos, Beograd, 1972., 15-33.

19 Anđelko Badurina, Iluminirani rukopisi samostana Male Braće u Dubrovniku, Radovi Instituta za povijest umjetnosti 1-2 (1972), 524. 
intenzivnim gospodarskim vezama s talijanskim jugom, a tijekom dinastije Anžuvinaca uspostavlja se prepoznatljiv kult zaštitnika pomoraca i putnika s kontaminiranjem kulta sv. Nikole Putnika. Valja istaknuti kako iz crkve sv. Nikole na Prijekome potječe i najzanimljiviji primjerak starijeg dubrovačkog zlatarstva koji je bio dosad posve nepoznat znanstvenoj javnosti. Riječ je o okovu matrikule Bratovštine mesara (San Nicolo dei beccari) ${ }^{20}$ iz godine 1378., što se čuvala u crkvi sv. Nikole na Prijekome do polovice 20. stoljeća. Druga Bratovština sv. Nikole imala je sjedište u franjevačkoj crkvi sv. Nikole u Stonu iz 1389. godine, te je i iz nje sačuvan srebrni okov sa svečevim likom. ${ }^{21} \mathrm{U}$ crkvi na Prijekome čuva se gotički kip sv. Nikole u malenoj kapeli oslikanoj baroknim freskama s prikazom svečevih čudesa. ${ }^{22}$

Jedan od prepoznatljivih društvenih i kulturoloških fenomena srednjovjekovlja zasigurno su hodočašća, potaknuta razvojem štovanja svetaca i njihovih moći, a to se odnosilo i na sv. Nikolu. ${ }^{23}$

20 Ivan Marija Mattei, Zibaldone, I, 103, 105; Zibaldone, II, 17, 499., Knjižnica Franjevačkog samostana Male braće u Dubrovniku; Serafin Crijević, Prologomena in sacram Metropolim Ragusinam ad illustrandam Ragusinae Provinciae Pontidicum Historiam necessaria, edita a F. S. M. C. R. O. P. C., Knjižnica dubrovačkog Dominikanskog samostana; Toma Ivanović, Pravvovjerstvo starieh mladiem Dubrovcjanom na isgled, Dubrovnik, 1804, 79; Frano Radić, Dvije najstarije sačuvane crkve grada Dubrovnika, Starohrvatska prosvjeta, 2 (1898), 82, 83; Giuseppe Gelcich, Dello sviluppo civile di Ragusa, Ragusa, 1884, 15; Kosta Vojnović, Bratovštine i obrtne korporacije u Republici Dubrovačkoj od XIII. do konca XVIII. vijeka, sv. II, Zagreb, 1909, 11-15; Državni arhiv Dubrovnik (dalje DAD), Rukopisna ostavština (dalje RO) don Nika Gjivanovića (dalje NG), CCCXIV/15: "(...) matricola con tavole di argento figurate matricola con statuette e piastre di argento (...)"; DAD, RO, NG, CCCXIV/11: ”(...) dello volume membrariceno statuto della confraternita religiosa dei beccari di S. Niccolò di Ragusa dell'anno 1378, legato in legno foderato di pelle, fregiata di argenti indorati l'esterno l'effige del santo Vescovo di Mira (...)”; DAD, 10.1. Testamenta notariae, sv. 1391. - 1402., f. 65' - u oporuci Chervatina Tuertcovicha od 24. 10. 1394. ostavlja se: "(...) a Sĉo Nicolo in piaça Ragusj pp ij (...)".

21 Kosta Vojnović, Bratovštine i obrtne korporacije u Republici Dubrovačkoj od XIII. do konca XVIII. vijeka, sv. I, Zagreb, 1899, 7; Vinicije B. Lupis, Sakralna baština Stona i okolice, Matica hrvatska Ston, Ston, 2000, 165; isti, Nove spoznaje o starijem dubrovačkom zlatarstvu, Peristil, 48 (2005.) 1, 33-44; isti, Dubrovačke srednjovjekoune zlatarske teme, Institut društvenih znanosti Ivo Pilar, Zagreb Dubrovnik, 2015., 258.

22 Niko Ggjivanović, Tri veoma sačuvane crkvice dubrovačke: "Sv. Nikola na Prijekom“, „Sv. Jakob na Pelinama“ i „Sigurat“, Glasnik dubrovačkog učenog društva „Sveti Vlaho“, Dubrovnik, 1929, 63-174; Željko Peković, Crkva sv. Nikole na Prijekom, SHP, 21 (1991.) 3, 159-170; Ivo Viđen i Veronika Šulić, Crkva sv. Nikole, u: Zidno slikarstvo grada Dubrounika pregledni katalog, (ur.) Veronika Šulić, Hrvatski restauratorski zavod, Dubrovnik, 2016., 52-53.

23 Opširnije o srednjovjekovnim hodočasničkim mjestima vidi: R. Oursel, Pellegrini nel Medio Evo. Gli uomini, le strade, i santuari, Jaca Book, Milano, 1979. 
Hrvatski je narod participirao i u toj manifestaciji srednjovjekovne duhovnosti, što se ponajviše očitovalo u oporučnim nakanama oporučitelja. Jednako tako su i Dubrovčani vrlo često ostavljali oporučne želje ili sami odlazili na hodočašća kako bi dobili oprost na mjestima kulta i pred svetačkim moćima. U oporukama građana često se spominju i legati ostavljeni za hodočasnička putovanja u: Asissi, Aleksandriju, Barlettu, Bari, Santiago de Compostela u Galiciji, Gargano, Padovu, Recanati, Trani, na Sinaj u samostan sv. Katarine, u Jeruzalem u baziliku Svetog groba. Osim osobnog odlaska česta je pojava ostavljanje legata za odlazak drugih osoba u oporučiteljevo ime, ali da se to učini, kako stoji u oporukama, "pro annima mea”, tj. za oporučiteljevu dušu. Ostavitelji su nalagali epitropima da pronađu nekog svećenika ili "pobožnu, zdravu i voljnu osobu” koja će hodočastiti umjesto njih, jer su oni sami spriječeni bolešću, starošću ili drugim razlogom da to osobno učine. U Dubrovniku je hodočašće bilo općeprihvaćeni oblik vjerskog očitovanja pučke pobožnosti. ${ }^{24} \mathrm{U}$ poznatoj oporuci dubrovačkog građanina Angela de Letitije od 5. svibnja 1348. uz brojne donacije nalaže se i neka se jedan svećenik pošalje u Monte Sant`Angelo i u Svetog Nikolu u Bari te u Svetu Mariju del Casale kod Brindisija i neka mu se za njegov trud dade 20 perpera. $^{25}$

\subsection{Sveti Nikola u Janjevu}

Sv. Nikola je također identitetski simbol dubrovačke dijaspore na Kosovu u mjestu Janjevu, čiji je najstariji spomen iz 1303. godine u pismu pape Benedikta XI. barskom biskupu Marinu. U pismu pape Klimenta VI. iz 1346. godine izričito se spominje Janjevo. ${ }^{26}$ Župna crkva sv. Nikole u Janjevu bila je pod jurisdikcijom Kotorske biskupije, a ona je u razdoblju od 1172. do 1828. (uz kraće prekide i ranije) bila u sastavu metropolije Canosa - Bari u Apuliji. ${ }^{27}$ Taj izravni južnotalijanski utjecaj treba tražiti u specifikumu štovanja kulta sv. Nikole kod Hrvata u Janjevu na dan 9. svibnja, kad je

\footnotetext{
24 Marijan Sivrić, Oporuke kancelarije stonskog kneza od sredine 15. stoljeća do 1808. godine, Državni arhiv Dubrovnik, Dubrovnik, 2002., 84.

25 Anamarija Bezek i Vinicije B. Lupis, Crkva Gospe Luncijate u Gružu Hortus marianus, Ogranak matice hrvatske u Dubrovniku , Dubrovnik, 2016., 24.

26 Nikola Čolak - Ive Mažuran, Janjevo sedam stoljeća opstojnosti Hrvata na Kosovu, Zagreb, 2000., 19-20.

27 http://www.kotorskabiskupija.me/biskupija/povijest/ (preuzeto 18. 6. 2021. u $10 \mathrm{~h})$.
} 
blagdan prijenosa moći sv. Nikole. ${ }^{28}$ Proljetni sv. Nikola postao je tako identitetski simbol Janjevca. Janjevci koji žive i rade na području Dubrovačke biskupije redovito obilježavaju taj blagdan kao zavičajnu identitetsku sastavnicu. Slavlje se upriličuje obično 9. svibnja u župnoj crkvi sv. Nikole u Cavtatu, uz koncelebraciju svećenika Janjevaca: don Josipa Mazarekića, don Roberta Čibarića i don Mata Karamatića. Misno slavlje nastavlja se zajedničkom večerom, kada Janjevci zapjevaju svoju himnu: „Nigdje nema ljepšeg kraja, nego što je Glama brijeg. To je pravi kutak raja, Domovine naše stijeg“. Isto tako Janjevci su u Kistanjama na 9. svibnja 2020. godine obilježili 20 godina od doseljenja i deset godina posvete nove župne crkve sv. Nikole. ${ }^{29}$ Prijenos moći sv. Nikole za dubrovačku kosovsku zajednicu postao je simbol okupljanja i zavičajnog identiteta, dok je sv. Vlaho simbol prazavičaja - grada Dubrovnika. Jedan od sugovornika $u$ intervjuima na slikovit način opisuje tu vezu i izražava izrazitu povezanost ove manjinske zajednice uz kult sv. Nikole:

„Ako je netko bio u Janjevu mogao je primijetiti na kipu sv. Nikole koji je okružen dječicom vrlo isturenu desnu ruku koja je inače ruka blagoslova, kao da želi odagnati sve neprijatelje od ovoga maloga stada koje mu je povjereno i koje se njemu povjerilo. I eto, stvarno nam je pomogao kroz sva ta stoljeća održati se katolicima i potomcima drevnih Dubrovčana i Hrvata i na tome smo mu veoma zahvalni. [...] Mi smo Janjevci uvijek imali jednu misao u svojim srcima - ostavili su naši pređi svetoga Vlaha da čuva Grad u svojoj ruci, a svetoga Nikolu Biskupa uzeli smo s nama kao zaštitnika trgovaca i putnika i time se nismo htjeli odvojiti od Katoličke Crkve. Jer tamo gdje je biskup, tamo je i Crkva“" (P. P., 60).

\subsection{Crkve i samostani posvećeni sv. Nikoli na području Dubrovačke biskupije}

Najbolji pokazatelj štovanja nekog kulta sveca jest brojnost oltara, kapela, crkava i samostana njemu posvećenih. U brojčanom iskazu crkava sv. Nikole na području Dubrovačke biskupije poslu-

28 Pasquale Corsi, La traslazione di san Nicola di Myra a Bari, u: San Nicola Splendore d'arte d'Oriente e d'Occidente, Milano, 2006., 89-96.

29 https://www.dubrovackabiskupija.hr/portal/index.php?option=com_k2\& view=item\&id=489:dubrova\%C4\%8Dki-janjevci-proslavili-blagdan-svogza\%C5\%A1titnika\&Itemid=466 (preuzeto 15. lipnja 2021. u 22 37h); https://laudato.hr/Novosti/Hrvatska/Dvadeseta-godisnjica-dolaska-Janjevaca-u-Kistanje. aspx (preuzeto 15. lipnja 2021. u 22 37h). 
žili smo se shematizmom i teritorijalnom podjelom po dekanatima, gdje je razvidna najveća koncentracija kulta sv. Nikole na užem gradskom području, s 19 crkava, samostana i kapela. Od ukupno 47 mjesta kulta koji se nalaze na području biskupije, 4 su crkvene župe posvećene ovom svecu, i to s najvećom koncentracijom na području Konavoskog dekanata, te tri samostana. Isto su tako sv. Nikoli bile posvećene tri bratovštine, ne ubrajajući crkvene bratovštine kao ustrojbene jedinice Dubrovačke Republike.

Dubrovački dekanat: Župa Gospe Velike: Sv. Nikola na Prijekome (predromanička crkva) po kojem se i gradski seksterij nazivao Sv. Nikola ili Prijeko ${ }^{30}$; Župa sv. Andrije na Pilama: Sv. Nikola na Gornjem Konalu u sklopu ljetnikovca Bete, Sv. Nikola u Dračastoj ulici 2; Župa sv. Mihovila Lapad: Sv. Nikola u sklopu ljetnikovca Beneša (spominje se 1348. - sagradio ga je Nikola Beneša ${ }^{31}$ ); Župa Svetog Križa: Sv. Nikola od Škara na Kantafigu (1286., a novu crkvu je sagradila je Bratovština brodograditelja 1527. godine) ${ }^{32}$; Koločep - Župa Velike Gospe: Sv. Nikola Grčki (izvorno Sv. Vid, predromanička crkva iz 9. st.) ${ }^{33}$; Lopud - Župa Gospe od Šunja: Sv. Nikola (predromanička crkva) ${ }^{34}$, crkva i samostan dominikanaca (sagrađen 1482.) ${ }^{35}$; Šipan - Suđurađ - Župa Gospe Velike: Sv. Nikola kraj Pakljene (sagradili su ga benediktinci 1323.); Kliševo - Župa sv. Mihovila: Sv. Nikola u Mravinjcu (restauriran u 19. st.); Majkovi - Župa Presvetog Trojstva: Sv. Nikola u Zabrežju; Orašac - Župa Porođenja Marijina: Sv. Nikola na Obrovu (14. st.); Trsteno - Župa sv. Vida: Sv. Nikola (kasnosrednjovjekovna crkva,

30 Kosto Vojnović, Crkva i država u dubrovačkoj republici, Rad JAZU, knjiga CXIX, Zagreb, 1994, 83-84; Vinicije B. Lupis, Neuspjeli pokušaj uspostavljanja dvanaest crkvenih župa dubrovačkog nadbiskupa Lodovica Beccadelija 1556. godine, Naša Gospa, 16 (1999.) 4, 12-14; Tomislav Marasović, Graditeljstvo starohrvatskog doba u Dalmaciji, Prostor 3 (1994.) 2, 453-455; Željko Peković, Dubrovnik. Nastanak i razvoj srednjovjekounog grada, Muzej hrvatskih arheoloških spomenika, Split, 1998., 42; isti, Četiri elafitske crkve, Centar Studia mediterranea Filozofskog fakulteta u Splitu, Dubrovnik - Split, 2008., 9-39; isti, Crkva Sv. Petra Velikoga dubrovačka predromanička katedrala i njezina skulptura, Centar studia Mediterranea Split, Filozofski fakultet Sveučilišta u Splitu, Dubrovnik - Split, 2010., 20.

31 Tomislav Macan, Crkve na području Župe velike, Zbornik Župe dubrovačke, 1 (1985.), 17-61.

32 Ivo Gugić, U zagrljaju grada Dubrovnika, Vrelo života, Trogir, 1980., 74-76.

33 Tomislav Marasović, nav. dj., Split, 1994., 86; Ivica Žile, Predromaničko crkveno graditeljstvo otoka Koločepa, Matica hrvatske, Dubrovnik, 2003., 75-96.

34 Tomislav Marasović, nav. dj., Split, 1994., 84.

35 Jasenka Gudelj, G/ 16 Lopud samostan sv. Nikole, u: Katalog izložbe Dominikanci u Hrvatskoj, Galerija Klovićevi dvori, Zagreb, 2011., 297-299. 
14. st.); Mokošica - Župa Svetog Spasa: Sv. Nikola (zavjetna crkva na groblju u Sustjepanu sagrađena je 2002., na spomen poginulim braniteljima); Rožat - Župa Velike Gospe: Sv. Nikola u Dračevu Selu (16. st.); Mandaljena - Župa sv. Marije Magdalene: Sv. Nikola u Čibači (19. st.), Sv. Nikola u Zakuli; Mlini - Župa sv. Ilara: Sv. Nikola u Solinama (14./15. st.); Sv. Nikola (nekoć Sv. Ruža Limska) u Srebrenom uz dvorac vlastelinske obitelji Bunić iz 16. st.; Nikolići na području Donjeg Brgata (srednjovjekovne ruševine crkve). ${ }^{36}$

Konavoski dekanat: Cavtat - Župa sv. Nikole: župna crkva sv. Nikole (sagrađena 1484.); Čilipi - Župa sv. Nikole: župna crkva sv. Nikole (16. st., nova je sagrađena 1840.) ${ }^{37}$; Dubravka - Župa sv. Nikole: Župna crkva sv. Nikole (1600., 1731. i 1935.) ${ }^{38}$; Gruda Župa Presvetog Trojstva: Sv. Nikola u Radovčićima (15. st., 1805., 1988.); Sv. Nikola u Zastolju (19. st., 1998.); Pridvorje - Župa sv. Srđa i Bakha: Sv. Nikola u Kuni (17. st.); Stravča - Župa sv. Jurja: Sv. Nikola u Šilješcima (17. st., sagrađena na starijoj crkvi); Vitaljina - Župa Svetog Spasa: Sv. Nikola u Mitrovićima (15. st., 1687.).

Korčulanski dekanat: Čara - Župa sv. Petra Apostola: Sv. Nikola u Čari (spominje se u povijesnim izvorima); Korčula - Župa sv. Marka: dominikanski samostan i crkva sv. Nikole (1480.) ${ }^{39}$; Račišće Župa sv. Nikole: župna crkva sv. Nikole (1794., 1907.) ${ }^{40}$; Vela Luka - Župa sv. Josipa: Sv. Nikola na Zloj Punti (1951.); Žrnovo - Župa sv. Martina: Sv. Nikola na putu za Banju, ruševina (14. st.); Lastovo - Župa sv. Kuzme i Damjana: Sv. Nikola između polja Kala i uvale Zace (15. st.); Sv. Nikola, ruševine iznad Portića na Sušcu (12. st.).

Pelješki dekanat: Kuna - Župa Velike Gospe: Sv. Nikola iznad Oskorušna (16. st.); Putnikovići - Župa sv. Marije Magdalene: Sv. Nikola na Lanterni u Brijesti, u trošnom stanju; Trpanj - Župa sv.

36 Tomislav Macan, Crkve na području Župe velike, nav. dj., Dubrovnik, 1985, 17-61; Arheološka baština Župe dubrovačke, katalog izložbe, Dubrovnik, Dubrovnik, 2007., 65.

37 Želimir Puljić, Ranjena Crkva u Hrvatskoj, uništavanje sakralnih objekata $u$ Hrvatskoj (1991. - 1995.), Dubrovačka biskupija, Zagreb, 1996, 91-129; Vinicije B. Lupis, O sakralnom graditeljstvu Konavala u 19. stoljeću; u: (ur.) Vladimir Stipetić, Konavle u prošlosti, sadašnjosti i budućnosti, Zavod za povijesne znanosti HAZU u Dubrovniku, Dubrovnik, 1998, 300.

38 Vinicije B. Lupis, Sloboda utemeljenja crkvenih župa dubrovačke nadbiskupije te Stonske i Trebinjsko-mrkanske biskupije u XVIII. stoljeću, Crkva u svijetu, 50 (2015.) 1, 82-99.

39 Stjepan Krasić, Pet stoljeća dominikanske nazočnosti u Korčuli 1498. - 1998., Hrvatska dominikanska provincija, Zagreb, 1998., 1-242.

40 Slavica Marković, Ćiril Metoda Iveković arhitekt i konzervator, Društvo povjesničara umjetnosti Hrvatske, Zagreb, 1992., 41-43. 
Petra i Pavla: Sv. Nikola (1840.); Žuljana - Župa sv. Martina: Sv. Nikola (1630.); ruševine srednjovjekovne crkve sv. Nikole na brdu Vrsi iznad Žuljane. ${ }^{41}$

Stonski dekanat: Lisac - Gospa od Rozarija: Sv. Nikola u Trnovici (kasnosrednjovjekovna crkva); Ošlje - Župa sv. Roka: Sv. Nikola na Gorici (srednjovjekovna); Ponikve - Župa sv. Ivana Krstitelja: Sv. Nikola u Boljenovićima (15. st.); Sv. Nikola u Dubi (1464.); Ston Župa sv. Vlaha; franjevački samostan sv. Nikole (1347.) ${ }^{42}$; Sv. Nikola u Česvinici (16. st., 1997.); Maranovići - Župa sv. Antuna Opata; Sv. Nikola u Okuklju (1626. - 1667.). ${ }^{43}$
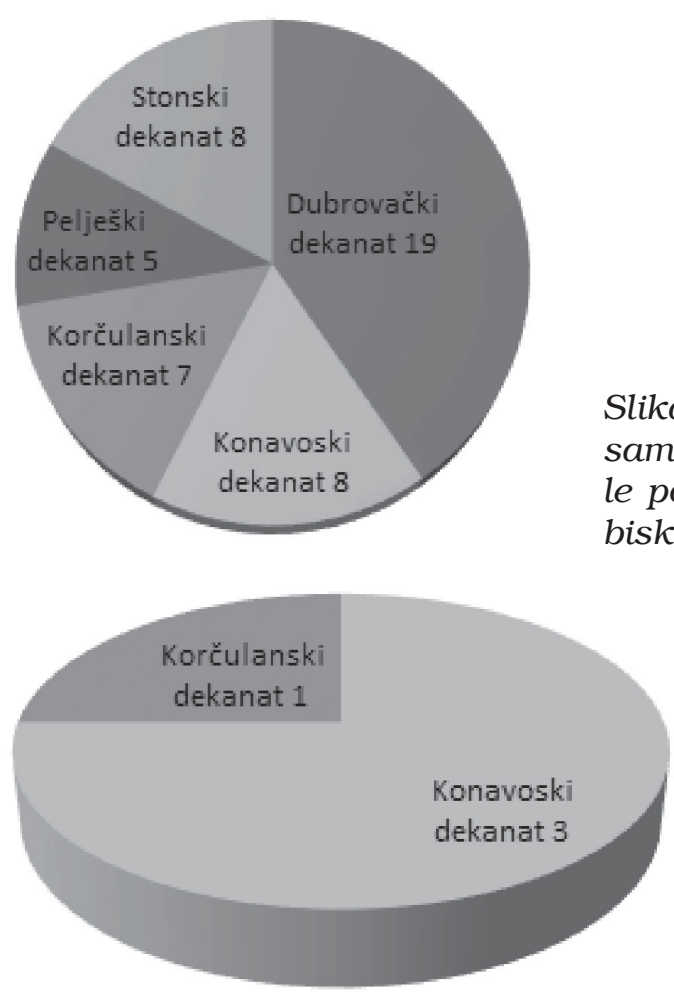

Slika 1: Župne crkve, kapele $i$ samostani s titularom sv. Nikole po dekanatima Dubrovačke biskupije

41 Vinicije B. Lupis, Sakralna baština Žuljane, Matica hrvatska, Ogranak Ston, Ston, 2007., 65-68.

42 Anđelko Badurina, Uloga franjevačkih samostana u urbanizaciji dubrovačkog područja, Institut za povijest umjetnosti, Zagreb, 1990., 74-80.

43 Vinicije B. Lupis, Sakralna baština Stona i okolice, Matica hrvatska Ston, Ston, 2000., 67-78; Ivan Šimić (ur.), Šematizam Dubrovačke biskupije, Dubrovačka biskupija, Dubrovnik, 2011., 1-402. Na temelju podataka iz shematizma izlučeni su podatci za analizu kulta sv. Nikole u Dubrovniku. 
Tablica 1: Franjevački i dominikanski samostani s titularom sv. Nikole po dekanatima Dubrovačke biskupije

\begin{tabular}{|c|c|c|c|c|}
\hline $\begin{array}{l}\text { Dubrovački } \\
\text { dekanat }\end{array}$ & $\begin{array}{l}\text { Konavoski } \\
\text { dekanat }\end{array}$ & $\begin{array}{l}\text { Korčulanski } \\
\text { dekanat }\end{array}$ & $\begin{array}{l}\text { Pelješki } \\
\text { dekanat }\end{array}$ & $\begin{array}{l}\text { Stonski } \\
\text { dekanat }\end{array}$ \\
\hline $\begin{array}{l}\text { Župa Gospe } \\
\text { od Šunja: } \\
\text { crkva i } \\
\text { samostan } \\
\text { dominikanaca } \\
\text { (sagrađen je } \\
\text { 1482.) }\end{array}$ & & $\begin{array}{l}\text { Korčula - Župa } \\
\text { sv. Marka: } \\
\text { dominikanski } \\
\text { samostan i } \\
\text { crkva (1480.) }\end{array}$ & & $\begin{array}{l}\text { Ston - Župa } \\
\text { sv. Vlaha: } \\
\text { franjevački } \\
\text { samostan } \\
\text { i crkva } \\
\text { (1347.) }\end{array}$ \\
\hline
\end{tabular}

Tablica 2: Bratovštine sv. Nikole s titularom sv. Nikole po dekanatima Dubrovačke biskupije

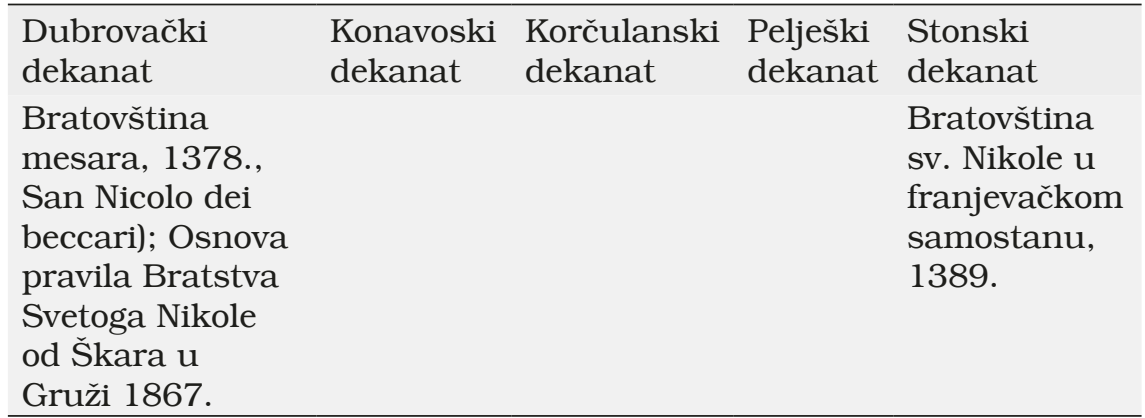

Slika 3: Franjevački i dominikanski samostani s titularom sv. Nikole po dekanatima Dubrovačke biskupije

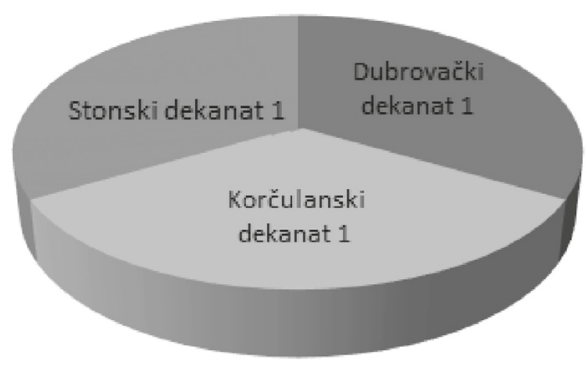

Slika 4: Bratouštine su. Nikole s titularom sv. Nikole po dekanatima Dubrovačke biskupije

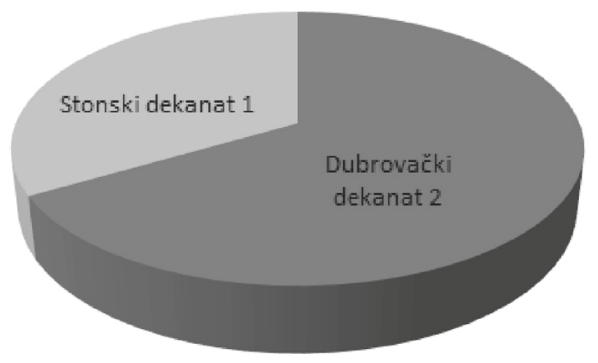




\section{SOCIOLOŠKA ANALIZA SUVREMENOG KULTA SV. NiKOLE} U DUBROVNIKU - TEORIJSKO POLAZIŠTE

Sociološka analiza polazi od teorije socijalne simbolizacije koja je nastala u okviru simboličkog interakcionizma, odnosno na teorijskoj perspektivi koja se djelomično naslanja na funkcionalističko shvaćanje Émilea Durkheima, a koju je u svom radu razvio G. H. Mead. Od ovakve koncepcije polazi i Trako Poljak, ${ }^{44}$ uvodeći razlikovanje između „univerzalnih“ i „partikularnih“ simbola, pri čemu se sv. Nikola može tumačiti kao partikularni simbol, odnosno, za razliku od univerzalno prihvaćenih općih simbola, ima vrlo specifično, tj. partikularno značenje u različitim povijesnim i socio-kulturnim kontekstima. Durkheim smatra kako u određenoj zajednici da bi došlo do društvene integracije mora postojati slaganje oko kolektivnih reprezentacija (simbola) te da rituali predstavljaju način održavanja simboličkih i moralnih granica zajednice. ${ }^{45}$

Mead $^{46}$ značenjske simbole (significant symbols) određuje kao one čija „smislenost uvijek pretpostavlja društveni proces iskustva ili ponašanja u kojem nastaje [...] uvijek se implicira univerzum diskursa kao kontekst u čijim odrednicama, ili kao polje unutar kojeg, značenjske geste ili simboli doista imaju smisao. Taj univerzum diskursa konstituira skupina individua koje provode zajednički društveni proces, i sudjeluju u zajedničkom društvenom procesu, iskustva i ponašanja unutar kojega te geste ili simboli imaju ista ili zajednička značenja za sve članove te skupine."

Na sličan način Cohen ${ }^{47}$ opisuje proces u kojem skupina ili zajednica kao simbolički konstrukt, ali i repozitorij simbola (vrijednosnih, normativnih i moralnih) sudjeluje $u$ izgradnji kolektivnog identiteta svojih članova. Istodobno članovi zajednice kontinuirano (re)kreiraju tu zajednicu konstruiranjem i dekonstruiranjem njezinih simbola. Cohen naglašava kako su društvene i fizičke granice i rituali koji ih definiraju od izuzetne važnosti za izgradnju zajednice, dok su naglašene sličnosti u kolektivnim identitetima socijalna konstrukcija podložna stalnoj povijesnoj promjeni. Treba napomenuti da se u ovakvom modelu zajednica ne upotrebljava u smislu

44 Tijana Trako Poljak, Percepcija religijskih simbola u hrvatskom društvu: križ, polumjesec i Davidova zvijezda, Socijalna ekologija 20 (2011.) 2, 147-175.

45 Émile Durkheim, Elementarni oblici religijskog života, Naklada Jesenski i Turk, HSD, Zagreb 2008.

46 George Herbert Mead, Um, osoba i društvo, Naklada Jesenski i Turk, Zagreb, 86.

47 Anthony P. Cohen, The Symbolic Construction of Community, Routledge, London. 2000 . 
zajednice urbanizirane, klasne, racionalizirane društvene strukture industrijskog društva, nego u mnogo fluidnijem smislu, koji se odnosi na „resurs i spremište značenja i referentnu točku“ kolektivnih identiteta i osjećaja pripadnosti. ${ }^{48}$

Neke studije pokazuju kako su identiteti izgrađeni unutar zajednica konstruirani u svakodnevnom životu kroz osobne interakcije i institucionalne prakse, ${ }^{49}$ ali i kroz specifične transformativne (i traumatične) događaje. ${ }^{50}$ (Re)kreiranje simbola i novih slojeva njihova značenja kroz vrijeme oblikuje identitete i ima potencijal da mijenja društvo neovisno o inicijalnom značenju koje su nosili. Analiza ovakvih transformacija unutar neke zajednice upućuje na paradigmatične priče i osjećaje koje dijele njezini članovi.

\subsection{Nalazi intervjua}

Podaci dobiveni intervjuima ukazuju da postoji izrazita slojevitost sv. Nikole i njegovog kulta na području dubrovačkog lokalnog konteksta. Tradicionalno značenje koje je kult ovog sveca imao za djecu, putnike i pomorce nadograđuje se događajima koji su se odvijali na blagdan sv. Nikole 1991. godine i simbolikom koja je iz toga proizašla. Naime, napad na Dubrovnik 6. prosinca 1991. godine trajao je cijeli dan i ostao je zapamćen kao najteže ratno razaranje u dubrovačkoj povijesti. Tijekom granatiranja izrazito je teško stradala stara gradska jezgra, a nakon prestanka granatiranja razbuktali su se požari koje su vatrogasci i građani gasili, pod napadima snajpera. Izuzetno se važna bitka odvijala na brdu Srđu, iznad Dubrovnika, oko utvrde Imperijal. Branitelji utvrde posljednjim su snagama uspjeli odbiti pokušaje neprijatelja da se probije u utvrdu i zauzme je.

O slojevitosti sv. Nikole kao simbola na značenjskoj razini svjedoče izjave sugovornika koji razlikuju značenje koje je taj svetac za njih imao u prošlosti i ono koje ima danas, pri čemu se dotiču transformativnog (traumatičnog) događaja iz 1991. kao ključnog za dodavanje novog simboličkog sloja vezanog uz sv. Nikolu:

„Sv. Nikola se od 1991. na ovamo, kad govorimo o Dubrovniku, gleda na jedan drugi način. Ne mogu ja danas misliti o sv. Nikoli

48 Cohen, nav. dj., 118.

49 Rogers Brubaker, Margit Feischmidt, Jon E. Fox, Liana Grancea, Nationalist Politics and Everyday Ethnicity in a Transylvanian Town. Princeton University Press, Princeton, 2006.; Jon E Fox, Cynthia Miller- Idriss, Everyday Nationhood., Ethnicities 8 (2008.) 4, 536-563.

50 Geneviève Zubrzycki, The Crosses of Auschwitz: Nationalism and Religion in PostCommunist Poland, University of Chicago Press, Chicago, 2006. 
bez da se sjetim svega što se tada dogodilo. Iako sam kao dijete sv. Nikolu vezivao uz regale, bječvice i čizmice, danas imam i neke druge asocijacije kad se sjetim [svetog Nikole]“ (M. B., 52). Pri tome treba napomenuti da postoji izrazito izraženo vremensko razlikovanje ovog simbola prije i poslije 1991. Govoreći o razdoblju prije Domovinskog rata, neki sugovornici sv. Nikolu značenjski povezuju uz početak predbožićnog doba i blagdana, odnosno običaj darivanja djece:

„Moja sjećanja su prije svega vezana uz regale koje sam dobivao. Rekao bih čak da je po pitanju darivanja to bio najvažniji i najuzbudljiviji blagdan, valjda i stoga što je dolazio nakon duljeg 'posta', a nakon sv. Nikole relativno brzo su slijedili Božić i Nova godina, tako da sam taj 6. prosinac iščekivao s posebnim uzbuđenjem“" (H. I., 56).

Za brojne dubrovačke obitelji čiji su članovi bili pomorci, sv. Nikola predstavlja simbol zaštite na moru i na putu:

„Sveti Nikola je zaštitnik putnika, njemu smo se uvijek obraćali prije čestih i dugih putovanja“ (V. M., 48).

„Sjećam se da su moja mati i none molile sv. Nikolu kad su pokojni otac ili nono išli na brod i dok su bili na brodu. Da se sretno vrate. I danas uz sv. Nikolu povezujem ovu tradiciju svoje obitelji i posebnost takvoga načina života kad ste razdvojeni od svojih. Nekako mi je to utješno kad sam dugo na moru“ (P. D., 42).

Unatoč razlikama primarnih značenjskih asocijacija koje sugovornici vezuju uz sv. Nikolu, svi raspoznaju sve nijanse njegovog simbolizma za suvremenu zajednicu. Isto tako, za neke sugovornike je novi sloj značenja posve „izbrisao“ onaj pučki i tradicionalni. Osobito je ovo vidljivo unutar skupine branitelja, od kojih neki ističu kako za taj dan nemaju posebnih asocijacija kad se radi o razdoblju prije 1991. godine. Sljedeći navod o tome svjedoči:

„Ne pamtim ništa posebno o blagdanu sv. Nikole prije 1991., nije to bio toliko istaknut ni važan blagdan za mene, ni za moju obitelj onda. Sad taj dan ima veće značenje za mene“ (B. B., 60). Dio sugovornika ističe i određeno žaljenje zbog činjenice da je najnoviji simbolički sloj nadjačao onaj tradicionalni:

„Što se pak značenja za Dubrovčane tiče, čini mi se da je sjećanje na 6. prosinca 1991. i sve ono što se toga dana obilježava, u velikoj mjeri zasjenilo pučku i vjersku komponentu Nikoljdana (H. I., 56).

Prikazane značenjske razlike reflektiraju se i na emocionalnoj i vrijednosnoj razini, pri čemu se emocije uzbuđenja i radosti, koje su 
se vezivale uz sv. Nikolu prije rata nadopunjuju osjećajem nevjerice, tuge i šoka u razdoblju nakon rata. Međutim, u vrijednosnom smislu, naglasak i dalje ostaje na zajednici i osjećaju pripadnosti, bilo $\mathrm{u}$ emotivno pozitivnoj bilo u negativnoj situaciji. Primjer pozitivnih emotivnih konotacija vezanih uz sv. Nikolu i njihovu povezanost uz zajednicu i tradiciju oslikava sljedeći citat:

„Sveti Nikola svetac je zaštitnik moje obitelji (pelješke grane), svaki drugi član nosi njegovo ime. Tako da me uz sveca vežu najtoplije uspomene, vrijeme pred Božić, moj nono i velika festa, zajedništvo obitelji“ (N. B., 30).

S druge strane, negativne emocije, opet ukorijenjene u specifično pamćenje zajednice, možemo vidjeti u sljedećem citatu:

„Ne govorim samo i isključivo o mojim osjećajima iako su ona primarna, govorim o Dubrovniku i blagdanu svetoga Nikole koji je na osobiti način ostalo u sjećanju Grada i to od onog blagdana 1991. naovamo. Nitko od onih koji je bio u Gradu tog petka, 6. prosinca na blagdan sv. Nikole, neće ga zaboraviti. [...] Svi koji smo izgubili nekoga taj dan, ali jednako i oni koji su izgubili neko materijalno dobro ili samo doživjeli rušenje i palež bez gubitaka, također znaju i mogu potvrditi da će taj dan i taj blagdan sv. Nikole zauvijek pamtiti kao što će ga pamtiti zauvijek i ovaj kameni Grad“ (M. U., 70).

Iako je na dan sv. Nikole Dubrovnik pretrpio najveće razaranje materijalne baštine i imao najviše ljudskih žrtava, dio ispitanika (osobito branitelja) uz taj dan vezuje i pozitivne osjećaje nade, zahvalnosti i dubokog zajedništva. Sveti Nikola na taj način nije samo simbol rušenja i stradanja nego i svojevrsnog preokreta i pobjede. Jedan od branitelja ovako opisuje svoje emocije:

„Taj dan smo pobijedili, taj dan smo shvatili da mi možemo pobijediti, da se ne moramo povlačiti, da je položaj koji držimo održiv i neosvojiv. Taj dan mi je potpuno drugu sliku stvorio o svemu onome što se do tad događalo. [...] Recimo, na Srđu taj dan, na tvrđavi nije poginuo nitko na našoj strani. Imali smo ranjene, ali nije nitko poginuo. To su događaji koji ti promijene život. Ako nisi imao prilike upoznati Boga, taj dan si vidio da postoji Bog. To je nešto posebno što rukovodi tobom u tom trenutku da ti zapravo ne znaš što radiš. Kao da smo bili vođeni Božjom rukom. Ja se ježim kad to govorim, ali to je istina. To je ono što sam ja osjetio“ (D. B., 59).

$\mathrm{Na}$ razini rituala vezanih $\mathrm{uz} \mathrm{sv}$. Nikolu, isto kao i u pogledu značenjskih i emocionalnih konotacija, mogu se razlikovati tradicionalni, pučki rituali i oni koji su vezani uz suvremenu povijest. Tra- 
dicionalni rituali uključuju misna slavlja (osobito ona u zavjetnim crkvama u Dubrovniku i okolici), procesije, darivanje djece, blagoslov pomoraca i kolendavanje. Sugovornici se prisjećaju:

„Za svetog Nikolu pripremale su se čizmice, crevje i bječvice. Nama se djeci prijetilo da nećemo ništa dobiti ako ne budemo dobri“ (L. S., 50).

„None mi je pričala vazda o čudima koji je činio sveti Nikola dječak s ribljom kosti u grlu, pomorci u pogibelji... Štovali smo ga se kao zaštitnika djece, mornara i putnika. Među susjedima je bilo nekoliko Nikola, pa smo im znali i kolendavat" (H. I., 56).

Dio sugovornika spominje i rituale koji su izravno vezani uz novi sloj značenja sv. Nikole kao simbola. Novi rituali uključuju spuštanje vijenaca u more, komemoracije na moru, odavanje počasti poginulim braniteljima kod Spomen-križa na groblju Boninovo, na muslimanskom dijelu groblja Boninovo, kod drugih spomen-obilježja poginulim braniteljima, kod Križa na Srđu, simbolu obrane Grada te na groblju u Sustjepanu kod kapelice sv. Nikole. Jedan od sugovornika opisuje svoj način obilježavanja blagdana sv. Nikole u ritualnom smislu:

„Na jedan skladan način, posjetimo groblje, odnesemo svijeće i vijenac s predstavnicima vlasti i udrugama iz Domovinskog rata. Jednostavno, sretnem se s prijateljima s kojima i dan danas možeš popričati o tim događajima. Svi smo mi nastavili svoje živote živjeti, svatko na svoj način, ne živi nitko od nas $\mathrm{u}$ prošlosti, ali mi se prisjetimo svega onoga što je bilo jer to je dio naše povijesti, dio onoga što nam je promijenilo živote. Pođemo na Srd ... To je za mene sveto mjesto, ja gore idem kao u crkvu“" (B. B., 60).

Prepoznavanje novih i starih simboličkih značenja sv. Nikole, snaga emocija koje se vezuju uz taj kult od prošlosti do danas, uhodane ritualne prakse (stare i nove) te upisan novi sloj značenja u materijalnoj baštini na konkretan način svjedoče o promjeni značenja simbola. Opisane promjene pridonose shvaćanju transformacije kulta sv. Nikole iz tradicionalnog - pučkog u moderni - urbani kult, stvoren u novijoj povijesti. Pri tome elementi tradicionalnog i suvremenog sloja značenja supostoje unutar zajednice, koja funkcionira kao bazen različitih značenja, vrijednosnih i emocionalnih konotacija te ritualnih praksi na temelju kojih pojedinci kreiraju kolektivni identitet kao pripadnici specifične zajednice. 


\section{ZAKLJUČAK}

Simboli i značenja koja im pridajemo variraju kroz društvene kontekste i vrijeme. Ovaj je rad interdisciplinarnim pristupom, kombinirajući povijesno i sociološko istraživanje nastojao prikazati promjene koje je kult sv. Nikole doživio u specifičnoj zajednici. Premda je istraživanje smješteno samo unutar granica određene zajednice (budući da polazi od pretpostavke da zajednica određuje sadržaj simboličkog bazena koji koriste njegovi pripadnici i da značenja pridružena simbolima mogu dovesti do zajedničkog razumijevanja u toj zajednici), ono ipak pokazuje inovativan način analize koja dopušta širu refleksiju o simbolima i njihovoj polisemnoj prirodi, kao i o pluraliziranim društvenim narativima koji su s njima povezani.

Najprije analizom povijesne koncepcije i senzibiliteta simbolizma sv. Nikole (koji se očituje u materijalnoj baštini, hodočašćima, ritualnim praksama itd.) te potom posebnog sloja značenja u suvremenom kontekstu (analiziranom kroz specifičan pogled na kult koji imaju pomorci i branitelji), ovaj je rad nastojao analizirati različite nijanse odabranog simbola. Pri tome je pokazao kako vjerski kult sv. Nikole od 1991. godine dobiva posve novu dimenziju i priključuje se drugim urbanim simbolima Grada - svjetovnim i vjerskim kultovima sv. Vlaha i Orlanda - kao treći gradski kult Dubrovnika. Sv. Nikola postaje tako u suvremenoj memoriji grada kult sveca zaštitnika branitelja Domovinskog rata. Ovdje se radi o posve jedinstvenom fenomenu u razvoju kulta sv. Nikole na svjetskim razmjerima, koji postaje antiratni svetac i svetac obranitelj.

\section{THE CULT OF ST. NICHOLAS - CHANGES THROUGH HISTORY AND ROLE IN BUILDING THE CONTEMPORARY IDENTITY OF DUBROVNIK}

\section{Summary}

The particularity of the Croatian national identity, seen through cultural and religious heritage, is in its diversity that reflects the Croatian centuries-old reality and various cultural and political influences. The position at the crossroads of civilizations and various influences have largely determined the nature of the Croatian national and religious heritage, which is an integral part of the Western European cultural circle. Dubrovnik is recognizable through its symbol - the Armenian saint St. Vlaho (Blasius), but also 
as the southernmost city with the urban secular cult of the knight Orlando. After the Croatian War of Independence, Dubrovnik gained the third cult along with two existing ones - the cult of St. Nicholas. It should be noted that the cult of St. Nicholas was never an important cult during the past of the Dubrovnik Republic and was never on the state list of holidays, but it remained in the domain of professional and family saints. The cult of St. Nicholas from the Byzantine Bari expanded to Ragusium, then part of the Byzantine theme of Upper Dalmatia during the 11th and 12th centuries. Through intensive economic ties with the Italian south, during the Anjou dynasty, it was contaminated with the cult of Nicholas the Traveler and established into a recognizable cult of protector of sailors and travelers. The cult of St. Nicholas on the territory of the Dubrovnik Republic got extremely strong following the conjuncture of maritime affairs during the 15th and 16th centuries, and in the 18th century, which can be seen from the construction of churches, chapels, monasteries, altars and through the naming of sailing ships. St. Nicholas is also an identity symbol of the Dubrovnik diaspora in Kosovo in Janjevo. Today Dubrovnik's community has a very specific notion of St. Nicholas as a symbol, because on that day, 6th of December 1991, the most severe attack on Dubrovnik took place by SerbianMontenegrin aggressors, resulting in numerous human victims and material damage. The aim of this paper is, in an interdisciplinary way - combining historical and sociological perspective, to gain the first scientific insight into the relationship between the concepts of religious symbol, identity and community using the example of the cult of St. Nicholas in Dubrovnik. Research has shown that since 1991 St. Nicholas as a symbol has gained a whole new dimension on a semantic, value, emotional and ritual level. The cult of St. Nicholas thus has become in the modern memory of the city the cult of the patron saint of the Croatian War of Independence veterans. This is a completely unique phenomenon in the development of the cult of St. Nicholas which in this specific community has become an antiwar saint and a saint-defender.

Key words: St. Nicholas, Dubrovnik, symbol, identity, cult transformation 